\title{
MODEL PEMBELAJARAN SEJARAH UNTUK MENINGKATKAN KESADARAN SEJARAH MELALUI PENDEKATAN INKUIRI
}

\author{
Herry Porda Nugroho Putro \\ Prodi Pendidikan Sejarah FKIP Universitas Lambung Mangkurat, Banjarmasin \\ ulunporda@yahoo.co.id
}

\begin{abstract}
The objectives of this research are to produce an inquiry model as a way to increase the history material comprehension and history consciousness of students in teaching and learning history. To achieve the objectives, the research was done by using the approach of research and development. In general, this research consists or three levels: (1) doing a pre-survey which identified the current condition of teaching and learning history, (2) developing a model based on the findings of pre-survey, (3) validating the model. Developing the model was done by limited experiments and unlimited experiments. The result of this research showed that that the inquiry model is effective to increase the material comprehension and history consciousness of students, it is relevant to be used in teaching and learning history, and effective to improve the performance of history teachers. Therefore, it can be concluded that the inquiry model is effective to be used to improve the quality of the process and products of teaching and learning history in junior high schools, especially in Banjarmasin City.
\end{abstract}

Key Words: a model of teaching, inquiry, history consciousness

\begin{abstract}
ABSTRAK
Penelitian ini bertujuan untuk menghasilkan produk berupa model inkuiri dalam rangka meningkatkan pemahaman materi dan kesadaran sejarah dalam pembelajaran sejarah. Untuk mencapai tujuan tersebut penelitian ini dilakukan dengan menggunakan pendekatan penelitian dan pengembangan. Secara garis besar tahapan penelitian ini meliputi (1) prasurvai untuk mengidentifikasi kondisi pembelajaran sejarah yang sedang berjalan, (2) pengembangan model berdasarkan hasil prasurvai, dan (3) validasi model. Pengembangan model dilaksanakan dengan uji coba terbatas dan uji coba luas. Temuan penelitian ini menghasilkan kesimpulan bahwa model inkuiri efektif untuk meningkatkan pemahaman materi dan kesadaran sejarah siswa, relevan digunakan dalam pembelajaran sejarah, efektif untuk meningkatkan kinerja guru, sehingga dapat disimpulkan bahwa model inkuiri efektif digunakan untuk meningkatkan kualitas proses dan produk pembelajaran sejarah di sekolah menengah pertama khususnya di kota Banjarmasin.
\end{abstract}

Kata Kunci: model pembelajaran, inkuiri, kesadaran sejarah

\section{PENDAHULUAN}

Pendidikan sejarah dalam era globalisasi diperlukan agar bangsa Indonesia memiliki kepribadian bangsa dan kesadaran sejarah yang kuat serta dapat terlibat aktif. Kesadaran sejarah

Paramita Vol. 22 No. 2 - Juli 2012 [ISSN: 0854-0039]

Hlm. 207-216 sebagai bentuk "rasa hayat historis" (Soedjatmoko, 1992: 56) memiliki posisi fundamental bagi keberadaan suatu bangsa.

Pendidikan sejarah pada era reformasi menghadapi tantangan sesuai fungsinya sebagai penyadaran "sense of belonging dan $\mathrm{n}$ asional- 
isme" (Wiriaatmadja, 2002: viii). Kesadaran sejarah diharapkan dapat memberikan rasa optimis penyelesaian masalah bangsa (Wiriaatmadja, 2002). Pendidikan sejarah dituntut sebagai wahana pemupukan semangat kebangsaan dalam gejolak multidimensional. Kesadaran sejarah lewat pendidikan sejarah dasar untuk membangun kesadaran akan kontinuitas dan sumber inspirasi mengbangkitkan rasa kebanggaan dan tanggung jawab (Kartodirdjo, 1988; Meullen, 1987). Pembelajaran sejarah pada era reformasi dituntut peran aktif siswa (students centered) dan historical thinking, sehingga siswa belajar menyelesaikan permasalahan sejarah.

Pendidikan sejarah sebagai wahana penumbuhan kesadaran sejarah dihadapkan kepada kondisi pembelajaran yang hapalan, siswa kurang diajak berintepretasi dan mengungkap makna sejarah (Wineburg, 2001). Seharusnya siswa diajak menelaah keterkaitan kehidupan yang dialami diri, masyarakat dan bangsanya (Kardisaputra, 2003).

Kurikulum baru sejarah menekankan pembelajaran contekstual teaching and learning (CTL) dengan pendekatan inkuiri (Depdiknas, 2002). Pendekatan ini diharapkan mampu mengembangkan keterampilan intelektual, sesuai ciri sejarah sebagai ilmu. History dalam bahasa Yunani istoria berarti inquiry, yaitu mencari agar tahu dan mencari informasi (Garvey and Krug, 1977; Sjamsuddin, 1999; Wiriaatmadja, 2002).

Dari latar belakang pemikiran di atas, tujuan penelitian ini adalah mengkaji model pembelajaran sejarah untuk meningkatkan kesadaran sejarah jenjang SMP dengan memperhatikan: karakteristik ilmu sejarah, kurikulum berbasis kompetensi, permasalahan bangsa, dan perkembangan iptek.

\section{METODE PENELITIAN}

Penelitian ini adalah Research and development atau (R \& D) (Borg and Gall, 2003). Validitas model dilakukan dengan eksperimen berbentuk kuasi eksperimen, yaitu disain eksperimen dengan pengontrolan sesuai dengan kondisi yang ada (situasional) (McMillan \& Schumacher, 2001: 342; Borg \& Gall, 2003: 402). Model inkuiri adalah variabel eksperimen, variabel kontrol adalah model konvensional. Desain penelitian adalah Pretest - Posttest Control Group Design (Fraenkel \& Wallen, 1993).

Lokasi penelitian SMP Negeri di Banjarmasin. Subjek penelitian guru dan siswa kelas dua. Subjek penelitian prasurvai 30\% dari jumlah SMP Negeri. Sampel penelitian tahap uji coba diambil secara purposive random sampling. Sekolah sampel uji coba diklasifikasikan berdasarkan letak sekolah, kota, agak pinggiran, dan pinggiran. Klasifikasi berdasarkan anggapan masyarakat, kondisi wilayah, dan ketersediaan sarana prasarana. Berdasarkan fokus penelitian dan jenis data, dalam penelitian ini digunakan empat instrumen untuk menjaring data, yaitu: (1) lembar observasi, (2) angket, (3) tes hasil belajar, dan (4) tes kesadaran sejarah.

Teknik pengolahan dan analisis data prasurvai dengan metode kualitatif untuk menggamgambarkan pembelajaran sejarah pada SMP di Kota Banjarmasin. Pada pengembangan model data observasi kelas dianalisis secara kualitatif selanjutnya direvisi dan diuji coba. Data kemampuan siswa dan kesadaran sejarah awal pembelajaran (pretest) dan akhir pembelajaran (posttest) dianalisis secara kuantitatif dengan uji t. Uji t juga digunakan untuk melihat hasil test setiap siklus uji coba sebagai bahan revisi siklus berikutnya hingga diperoleh model akhir. Pada tahap validasi model analisis kualitatif 


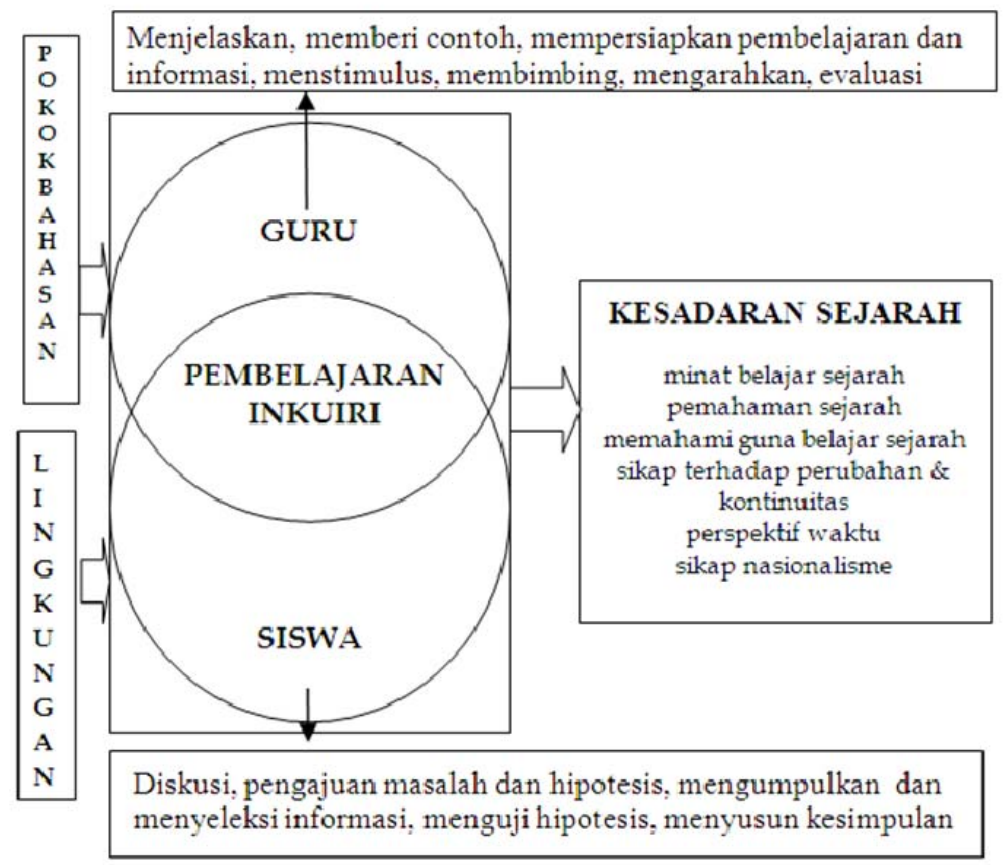

Gambar 1. Bagan Model Pembelajaran untuk Meningkatkan Kesadaran Sejarah

dilakukan pada data hasil observasi kelas untuk melihat gambaran efektifitas model, sedangkan analisis kuantitatif dengan uji $t$ untuk membandingkan kemampuan siswa dan kesadaran sejarah pretest dan posttest antara kelompok eksperimen dan kelompok kontrol. Analisis Varian digunakan untuk membandingkan kemampuan dan kesadaran sejarah siswa berdasarkan kategori letak sekolah. Analisis kuantitatif dalam penelitian ini menggunakan bantuan program SPSS.

\section{HASIL DAN PEMBAHASAN}

\section{Hasil Prasurvai}

Guru sejarah di SMP Negeri Kota Banjarmasin sebagian besar berlatar belakang pendidikan sejarah. Guru sejarah menyadari bahwa mengajar sejarah bertujuan mengembangkan sikap dan perilaku kesejarahan, pewarisan nilai-nilai, dan sikap kebangsaan. Menurut se- bagian besar guru model-model pembelajaran sejarah penting Dikembangkan agar siswa lebih aktif. Aktivitas ilmiah sesuai karakteristik keilmuan sejarah perlu Dikembangkan dalam pembelajaran sejarah, salah satunya dalam bentuk pendekatan inkuiri.

Kurikulum berbasis kompetensi sudah dikenal sebagian besar guru. Sarana dan prasarana di sekolah kurang mendukung keberhasilan pembelajaran. Evaluasi pembelajaran sejarah selama ini kurang sesuai dengan karakter ilmu sejarah. Siswa berharap guru sejarah memberikan kesempatan diskusi, aktif, dan memberikan contoh-contoh peristiwa sehari-hari dan dengan menggunakan sumber-sumber sejarah. Pelajaran sejarah kurang diminati, karena kurang menarik. Guru dominan dalam pembelajaran, keterampilan intelektual kurang dikembangkan. Evaluasi menggunakan LKS yang tidak disusun sendiri oleh guru. Bagan model pembelajaran sejarah yang Dikembangkan adalah seperti pada gambar 1 . 


\section{Hasil Pengembangan Model}

Kegiatan pembelajaran sejarah untuk meningkatkan kesadaran sejarah melalui pendekatan inkuiri dilakukan melalui beberapa tahap. Pertama, tahap pendahuluan. Pada tahap ini, siswa dilibatkan dalam persiapan pembelajaran. Penyampaian tujuan pembelajaran dapat menumbuhkan kesadaran siswa tentang manfaat pokok bahasan. Penjelasan model inkuiri membantu melancarkan pembelajaran. Keberhasilan menumbuhkan minat dan motivasi pada tahap pendahuluan berpengaruh terhadap pembelajaran berikutnya.

Kedua, tahap pengajuan masalah. Beberapa kegiatan pada tahap ini adalah penjelasan materi pembelajaran lebih berhasil dengan dialog, menggunakan media pembelajaran (bagan, gambargambar). Penjelasan lebih berhasil bila siswa telah mempersiapkan materi pembelajaran dan informasi penunjang, guru menghubungkan materi pembelajaran secara kontekstual dan aktual. Peristiwa sejarah di sekitar siswa (daerah) membantu menumbuhkan minat dan pemahaman tentang peristiwa sejarah. Pembagian waktu harus secara tegas diperhatikan guru. Dorongan dan bimbingan guru diperlukan secara penuh. Contoh bentuk permasalahan sangat membantu siswa. Permasalahan berbentuk pertanyaan keterampilan intelektual. Guru dituntut memperhatikan dan menghargai setiap permasalahan yang diajukan siswa. Seleksi semua permasalahan secara bersama-sama dan diskusi. Permasalahan yang diajukan dibacakan dan ditulis pada papan tulis oleh siswa. Siswa mampu mengembangkan permasalahan kontroversial.

Ketiga, tahap pengajuan hipotesis. Contoh hipotesis berbentuk peristiwa sehari-hari memudahkan untuk penyusunan hipotesis. Bimbingan dan dorong- an guru diperlukan agar siswa mampu menyusun hipotesis dengan benar. Hipotesis yang diajukan siswa sudah disertai alasan. Untuk menumbuhkan penghargaan dan motivasi semua hipotesis yang diajukan siswa (benar atau salah) ditampung dan ditulis pada papan tulis, selanjutnya diseleksi bersamasama. Kesadaran sejarah terlihat dari munculnya aspek-aspek kesejarahan dalam hipotesis, menghargai pendapat orang lain, kebersamaan, dan alasan mengajukan hipotesis.

Keempat, penggalian informasi. Pada tahap ini, guru telah menyediakan bahan-bahan sebagai sumber informasi. Bimbingan dan dorongan guru diperlukan agar siswa dapat mengumpulkan, menyeleksi, dan menyusun informasi dengan benar. Guru perlu memberikan contoh dan penjelasan tujuan dilakukan penggalian informasi. Siswa mampu mempersiapkan dan mengumpulkan informasi sebelum pelajaran di mulai. Kelengkapan informasi dapat menumbuhkan minat siswa. Siswa mampu menentukan hubungan antara satu kumpulan informasi dengan kumpulan informasi lainnya, pokok-pokok pikiran yang mendasari suatu informasi, dan mampu menarik konsekuensi dari informasi baik dalam waktu maupun dimensi. Kesadaran sejarah siswa terlihat dari aktivitas menggali, mengolah, menggunakan informasi, dan memahami makna yang terdapat dalam sumber-sumber informasi kesejarahan.

Kelima, pengujian hipotesis. Di tahap ini, bimbingan, dan contoh uji hipotesis dari guru diperlukan. Kesadaran sejarah siswa terlihat dari diskusi, menganalisis, menghubungkan hipotesis yang telah diajukan dengan informasi yang telah diperoleh.

Keenam, menyusun kesimpulan. Di tahap ini, bimbingan, dan contoh kesimpulan dari guru tetap diperlukan. 
Siswa aktif menyusun dan mengajukan hipotesis.

Pada pembelajaran sejarah dengan model inkuiri, kinerja guru menjadi penting untuk mengarahkan dan memberikan pendampingan bagi siswa. Kinerja Guru pada tiap tahap harus mampu memberi fasilitas pada siswa untuk mengembangkan kemampuan melakukan pemecahan masalah. Pada tahap pendahuluan, guru dituntut untuk mampu melibatkan siswa mempersiapkan sarana pembelajaran, tanya jawab dan mengembangkan interaksi. Guru harus mampu menumbuhkan perhatian siswa dengan gambar-gambar, serta mengajak siswa mengamati, menunjukkan, dan menjelaskan gambar -gambar.

Pada tahap pengajuan masalah, guru dituntut untuk menjelaskan tujuan, model pembelajaran, garis besar pokok bahasan. Selain itu, guru harus memberikan contoh peristiwa sejarah dan penyusunan masalah. Kemudian, guru membimbing dan mendorong siswa menyusun dan mengajukan permasalahan serta menjelaskan konsepkonsep.

Di tahap pengajuan hipotesis, guru menjelaskan pengertian, tujuan menyusun hipotesis. Kemudian memberikan contoh hipotesis, serta membimbing, dan mendorong siswa menyusun hipotesis, mengajukan hipotesis, menyeleksi hipotesis.

Dalam tahap penggalian informasi, guru juga berperan dalam menjelaskan tujuan dan cara menggali informasi, memberi contoh menggali informasi, mempersiapkan bahan-bahan. Selain itu, guru juga harus tetap membimbing mengolah, menyusun informasi, dan menghubungkan informasi yang diperolehnya.

Pada tahap menguji hipotesis, guru menjelaskan tujuan menguji hipotesis dan membimbing menghubung- kan informasi yang diperoleh dengan hipotesis. Kemudian pada tahap menyusun simpulan, guru menjelaskan tujuan dan memberi contoh kesimpulan. Selain itu, guru membimbing menyusun kesimpulan berdasarkan uji hipotesis yang telah dilakukan siswa.

Pada tahap tindak lanjut, guru melakukan Menjelaskan tujuan dan memberi contoh kesimpulan. Kemudian membimbing menyusun kesimpulan berdasarkan uji hipotesis yang telah dilakukan siswa.

Ditinjau dari aspek aktivitas belajar siswa, pembelajaran dengan model inkuiri dapat mengembangkan aktifitas siswa. Siswa didorong mengajukan permasalahan, memecahkan masalah (dengan hipotesis), mengamati peristiwa sejarah dalam bentuk gambargambar (menggali informasi) serta menyampaikan kesimpulan.

Keberhasilan pembelajaran menggunakan model inkuiri terlihat juga dari meningkatnya hasil belajar siswa. Hasil uji t kemampuan siswa sebelum uji coba (pretest) dengan sesudah uji coba (posttest) pada uji coba terbatas maupun uji coba luas menunjukkan perbedaan yang signifikan, yaitu $t_{\text {hitung }}>t_{\text {tabel. }}$ Kemampuan siswa pada setiap uji coba (lingkup terbatas maupun lingkup luas) mengalami peningkatan, diperlihatkan oleh hasil uji t posttest dengan sampel berpasangan pada setiap antar siklus.

Kesadaran sejarah siswa sejak tahap pertama hingga tahap terakhir pada uji coba terbatas dan uji coba luas meningkat. Minat belajar, pemahaman sejarah, pemahaman dan sikap terhadap perubahan dan kontinuitas, perspektif waktu, dan sikap nasionalisme sebagai indikator kesadaran sejarah sejarah telah berkembang pada diri siswa. Indikasi ini terlihat dari keterlibatan siswa secara aktif dan aktivitas ilmiah dalam pemecahan masalah. 
Analisis uji $\mathrm{t}$ kesadaran sejarah siswa sebelum uji coba (pretest) dengan sesudah uji coba (posttest) lingkup terbatas maupun lingkup luas menunjukkan peningkatan yang signifikan pada kesadaran sejarah siswa, nilai $t$ hitung $>t$ tabel. Kesadaran sejarah siswa pada setiap siklus uji coba juga meningkat, diperlihatkan oleh hasil uji t sampel berpasangan dengan nilai $t_{\text {hitung }}>$ nilai $t_{\text {tabel. }}$.

\section{Hasil Validasi Model}

Hasil validasi model menunjukkan bahwa kegiatan pembelajaran lebih menarik dan mengembangkan keterampilan berpikir. Hal ini tampak pada suasana pembelajaran lebih hidup dan dinamis. Guru mampu menyajikan contoh-contoh kontekstual. Guru mampu mengembangkan berbagai keterampilan mengajar. Siswa mampu menyusun secara sederhana peristiwa sejarah.

Pembelajaran sejarah lebih jelas dan terarah dengan model inkuiri. Hal ini ditunjukkan dengan berkembangnya kemampuan siswa dalam belajar secara ilmiah. Materi dapat dikemas dalam bentuk permasalahan. Materi lebih terarah sesuai permasalahan, sehingga mudah dipahami. Tumbuh sikap positip siswa : empati, kepedulian, menghargai dan menghormati, kerjasama, demokratis, kemanusiaan, dan kebebasan. Guru mampu mengembangkan historical thinking dalam bentuk permasalahan, pengajuan hipotesis, dan interpretasi sumber-sumber.

\section{Implikasi Model terhadap Pemahaman Materi}

Keunggulan model pembelajaran dalam meningkatkan pemahaman materi siswa terlihat pada uji validasi, yaitu perbandingan hasil posttest antara kelompok ekperimen (KE) dengan kelompok kontrol (KK). Nilai $\mathrm{t}$ hitung 17.648; 18.096; dan $20.536>$ nilai $t$ tabel a $0.05=1.66$; dan nilai Sig (2-tailed) $=0.000$ $<$ setengah $\mathrm{a}=0.025$.

Perbedaan kemampuan siswa (posttest) sekolah eksperimen dan sekolah kontrol di tengah kota diperlihatkan oleh $\mathrm{t}$ hitung 16.567; 17.386; dan 17.653 > nilai $t$ tabel dengan derajat kebebasan $(\mathrm{df})$ 36 yaitu 1.69; dan nilai Sig (2-tailed) = $0.000<$ setengah $\mathrm{a}=0.025$.

Perbedaan kemampuan siswa (postttest) antara kelompok kontrol (SG) dengan kelompok ekperimen (SGX) di daerah agak tengah kota terlihat dari $\mathrm{t}$ hitung 10.779; 10.215; dan $11.703>\mathrm{t}$ tabel dengan derajat kebebasan (df) 36 yaitu 1.69, dan nilai Sig (2-taled) $=0.000<$ setengah a $=0.025$.

Perbedaan kemampuan siswa (postttest) antara kelompok ekperimen (SPX) dengan kelompok kontrol (SP) di daerah pinggiran kota terlihat dari hasil $\mathrm{t}$ hitung 9.37; 12.158; dan $12.158>$ harga $\mathrm{t}$ tabel dengan derajat kebebasan (df) $37=$ 1.69, dan nilai Sig (2-taled) $=0.000<$ setengah $\mathrm{a}=0.025$, berarti skor posttest kemampuan siswa kelompok eksperimen di sekolah pinggiran lebih baik dibandingkan dengan kelompok kontrol.

Kemampuan siswa berdasarkan letak sekolah pada kelompok eksperimen juga terdapat perbedaan. Hasil analisis varian tiga kali posttest $\mathrm{F}$ hitung 64.535; 77.421; dan $72.969>$ nilai $\mathrm{F}$ tabel $=$ 3.08 (df 2 dan 114). Hasil analisis ini memperlihatkan dalam kelompok eksperimen terdapat perbedaan kemampuan yang signifikan antara kategori sekolah di tengah kota, agak tengah kota.

Perbedaan posttest kemampuan siswa berdasarkan kategori letak sekolah untuk kelompok kontrol, hasil analisis varian tiga kali posttest untuk kelompok kontrol dengan df 2 dan 109; $F$ hitung $3.915 ; 5.324 ; 3.640>\mathrm{F}$ tabel $=3.08$. Hasil 
analisis varian ini menunjukkan terdapat perbedaan yang signifikan skor posttest kemampuan siswa dalam kelompok kontrol berdasarkan kategori sekolah (tengah kota, agak tengah kota, dan pinggiran kota), artinya penelitian ini telah memperlihatkan gambaran nyata bahwa letak sekolah di kota Banjarmasin berpengaruh terhadap kemampuan kesejarahan siswa.

Berdasarkan analisis varian di atas diketahui bahwa model inkuri yang Dikembangkan dapat meningkatkan kemampuan siswa SMP Negeri untuk semua letak sekolah (tengah kota, agak tengah kota, dan pinggiran kota)

\section{Implikasi Model Terhadap Kesadaran Sejarah Siswa}

Keunggulan model pembelajaran dalam meningkatkan kesadaran sejarah siswa dilakukan dengan membandingkan hasil posttest antara kelompok ekperimen (KE) dengan kelompok kontrol (KK). Nilai $t$ hitung 12.069; 21.140; dan $31.074>$ nilai $t$ tabel a $0.05=1.66$; dan nilai Sig $(2$-taled $)=0.000<$ setengah $a=$ 0.025 . Hal ini berarti terdapat perbedaan hasil posttest kesadaran sejarah siswa pada kelompok kontrol dengan hasil posttest kesadaran sejarah siswa pada kelompok eksperimen.

Uji $\mathrm{t}$ skor posttest kesadaran sejarah siswa pada sekolah di tengah kota kelompok eksperimen (SKX) dengan kelompok kontrol (SK) adalah: $\mathrm{t}$ hitung 8.720; 12.313; dan $23.872>t$ tabel dengan derajat kebebasan (df) 36 yaitu 1.69, dan nilai Sig $(2$-taled $)=0.000<$ setengah $\mathrm{a}=$ 0.025 . Hasil $t$ hitung dan nilai signifikan tersebut berarti perolehan skor posttest kesadaran sejarah siswa kelompok eksperimen lebih baik dibandingkan dengan kelompok kontrol.

Perbedaan kesadaran sejarah siswa (postttest) antara kelompok kon- trol (SG) dengan kelompok ekprimen (SGX) di daerah agak tengah kota terlihat dari nilai $\mathrm{t}$ hitung 11.319; 18.619; dan $24.292>\mathrm{t}$ tabel dengan derajat kebebasan (df) 36 yaitu 1.69, dan nilai Sig (2-taled) $=0.000<$ setengah $\mathrm{a}=0.025$. Hal ini menunjukkan signifikansi perbedaan antara hasil posttest sekolah agak tengah kota antara sekolah eksperimen dengan sekolah kontrol, berarti perolehan skor posttest kesadaran sejarah siswa kelompok eksperimen di sekolah agak tengah kota lebih baik dibandingkan dengan kelompok kontrol.

Perbedaan kesadaran sejarah siswa (postttest) antara kelompok kontrol (SP) dengan kelompok ekprimen (SPX) di daerah pinggiran kota terlihat dari nilai $t$ hitung 10.68; 17.51; dan 24.77 > harga $\mathrm{t}$ tabel dengan derajat kebebasan (df) $37=1.69$, dan nilai Sig (2-taled) = $0.000<$ setengah $\mathrm{a}=0.025$. Hasil $\mathrm{t}$ hitung tersebut menunjukkan signifikansi perbedaan antara hasil posttest kesadaran sejarah siswa pada sekolah di pinggiran kota untuk sekolah eksperimen dengan sekolah kontrol, berarti skor posttest kesadaran sejarah siswa di sekolah pinggiran pada kelompok eksperimen lebih baik dibandingkan dengan kelompok kontrol.

Tiga kali posttest kesadaran sejarah pada kelompok eksperimen pada validasi model ternyata nilai $\mathrm{F}$ hitung 33.786; 31.579; dan $32.787>$ dari nilai $F$ tabel (3.08) dengan derajat kebebasan 2 : 114. Hasil $\mathrm{F}$ hitung ini memberikan indikasi bahwa dalam kelompok ekperimen terdapat perbedaan kesadaran sejarah siswa yang signifikan antara kategori sekolah berdasarkan letaknya di tengah kota, agak tengah kota, dan pinggiran kota.

Demikian juga hasil analisis varian atas skor kesadaran sejarah siswa kelompok kontrol hasil tiga kali posttest kesadaran sejarah siswa untuk kelompok kontrol dengan derajat kebebasan 
2 : 109 juga memperlihatkan $\mathrm{F}$ hitung 7.336; 7.318; dan 7.228 > F tabel (3.08). Analisis ini menunjukkan bahwa terdapat perbedaan yang signifikan perolehan skor posttest kesadaran sejarah siswa dalam kelompok kontrol berdasarkan katagori letak sekolah. Hal ini berarti bahwa letak sekolah yang dijadikan sebagai dasar pengklasifikasian sampel sekolah dalam penelitian ini memperlihatkan gambaran yang sebenarnya.

Berdasarkan hasil analisis data di atas terlihat bahwa model inkuiri dalam pembelajaran sejarah yang Dikembangkan pada penelitian ini dan uji validasi pada sekolah eksperimen ternyata memiliki dampak yang positif untuk semua katagori sekolah. Sekolah kontrol dengan menggunakan model pembelajaran sejarah yang umum digunakan guru sejarah terutama ceramah menunjukkan skor yang berbeda berdasarkan katagori sekolah. Berarti model pembelajaran sejarah yang Dikembangkan oleh guru sejarah dipengaruhi juga oleh lo- kasi sekolah, khususnya kesadaran sejarah siswa. Berpijak pada hasil uji coba terbatas, uji coba luas, dan uji validasi, maka bagan model adalah seperti pada gambar 2 .

Model akhir pembelajaran sejarah untuk meningkatkan kesadaran sejarah melalui pendekatan inkuiri dibagi menjadi dua, yakni tahap desain dan tahap implementasi. Pada tahap desain, beberapa ketentuan pelaksanaan pembelajaran adalah sebagaimana pada tabel 1 .

Pada tahap implementasi, terdapat enam tahap yang dikembangkan. Tahapan tersebut dapat dilihat pada tabel 2. Pelaksanan pembelajaran ditunjang dengan sumber berupa buku teks sejarah dan buku-buku penunjang, Foto sejarah, gambar sejarah, peta, dan pelaku sejarah atau orang-orang sejaman. Setelah itu dilakukan evaluasi dengan dua model penilaian, yakni untuk mengetahui kesadaran sejarah digunakan isian dengan skala Likert, kemudian untuk mengetahui kemampuan siswa digunakan tes dalam bentuk soal uraian.

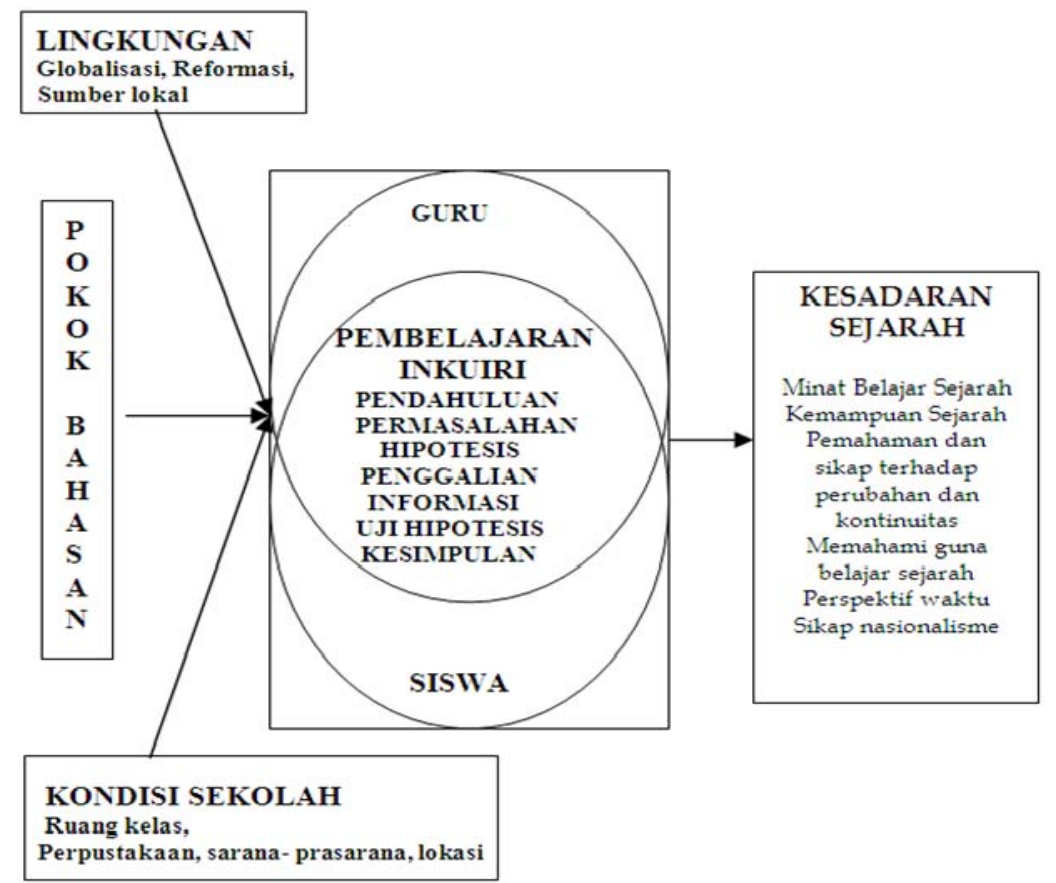

Gambar 2. Bagan dari Model Akhir Pembelajaran Sejarah untuk Meningkatkan Kesadaran Sejarah Melalui Pendekatan Inkuiri 


\section{SIMPULAN}

Model inkuiri dalam pembelajaran sejarah dapat menjawab tantangan globalisasi, reformasi, dan kondisi pembelajaran saat ini. Kemampuan intelektual dalam bentuk berpikir ilmiah melalui model inkuiri dapat diimplementasikan dalam pembelajaran sejarah. Aktivitas pembelajaran dalam bentuk tahapantahapan ilmiah dapat dilakukan siswa jenjang SMP.

Model inkuiri dalam pembelajaran sejarah sesuai tuntutan reformasi dan dapat digunakan untuk meningkatkan kesadaran sejarah. Hal ini terlihat dari meningkatnya kemampuan berpikir kesejarahan (historical thinking), dan kemampuan memecahkan permasalahan sejarah secara ilmiah. Temuan penelitian menunjukkan bahwa siswa mampu menjelaskan dan menganalisis perubahan dan kontinuitas, nasionalisme, guna sejarah, dan perspektif tentang waktu.

Aktivitas siswa pada pembelajaran sejarah melalui model inkuiri terlihat lebih aktif. Pembelajaran terkesan demokratis dan hangat dengan menempatkan siswa sebagai pebelajar, guru berperan sebagai motivator dan pembimbing. Temuan penelitian menunjukkan bahwa keluwesan guru mengimplementasikan model inkuiri berpengaruh terhadap minat dan motivasi siswa.

Kreativitas guru dan siswa diperlukan dalam mempersiapkan informasi dalam pembelajaran sejarah dengan model inkuiri. Temuan penelitian menunjukkan bahwa kreativitas guru mempersiapkan informasi dalam bentuk buku-buku, gambar-gambar, dan bagan-bagan dapat menciptakan suasana berinkuiri. Siswa terlihat bersemangat dan tertarik mengumpulkan informasi. Sedangkan stimulus guru dalam bentuk pemberian penguatan dan contoh-contoh informasi, dapat menggugah siswa terlibat mempersiapkan informasi sebagai persiapan, yaitu dengan membawa buku penunjang, gambar-gambar, bahkan hasil wawancara dengan pelaku sejarah.

\section{DAFTAR PUSTAKA}

Fraenkel, J.R. \& Wallen, N.E. 1993. How to Design and Evaluate Research. New York : McGraw-Hill Inc.

Garvey, B. \& Krug, M. 1977. Models of History Teaching in the Secondary School. Oxford: Oxford University Press.

Kardisaputra, O. 2003. “Beberapa Ciri Khas Ilmu Sejarah dan Implikasinya dalam Pengajaran Sejarah" dalam Sjamsuddin, H. \& Suwirta, A. Historia Magistra Vitae: Menyambut 70 Tahun Prof. Dr. Hj. Rochiati Wiriaatmadja, M.A. Bandung: Historia Utama Press.

Meullen, W.J.Vander. 1987. Ilmu Sejarah dan Filsafat. Yogyakarta: Kanisius.

Millan, M. \& Schumacher, S. (2001). Research in Education. London: Longman.

Sjamsuddin, H. 1999."Sejarah dan Pendidikan Sejarah". Mimbar Pendidikan. Nomor 2, Tahun XVIII, 1999. Bandung: University Press IKIP Bandung.

Soedjatmoko. 1992. "Antara Filsafat dan Kesadaran Sejarah" dalam William H. Frederick dan Soeri Soeroto. (1982). Pemahaman Sejarah Indonesia Sebelum dan Sesudah Revolusi. Jakarta : LP3ES

Wineburg, S. 2001. Historical Thinking and Other Unnatural Acts: Charting the Future of Teaching the Past. Philadelphia: Temple University Press.

Wiriatmadja, R. 2002. “Menyegarkan Kembali Model Pendekatan Inkuiri di Kalangan Pengajar Sejarah". Pendidikan Sejarah di Indonesia Perspektif Lokal, Nasional, dan Global. Bandung: Historia Utama Press. 
Tabel 1. Desain Pembelajaran untuk Meningkatkan Kesadaran Sejarah Melalui Pendekatan Inkuiri

\begin{tabular}{|c|c|}
\hline Komponen & Uraian \\
\hline Tujuan Pembelajaran & $\begin{array}{l}\text { 1. Menumbuhkan kesadaran sejarah } \\
\text { 2. Menumbuhkan keterampilan intelektual siswa }\end{array}$ \\
\hline Materi Pembelajaran & $\begin{array}{l}\text { 1. Gambaran peristiwa sejarah } \\
\text { 2. Kronologis dan kausalitas dalam peristiwa sejarah } \\
\text { 3. Perubahan dalam peristiwa sejarah } \\
\text { 4. Kontinuitas dalam peristiwa sejarah } \\
\text { 5. Kaitan antara masa lalu, masa kini, dan masa akan datang } \\
\text { 6. Manfaat belajar sejarah } \\
\text { 7. Kebangkitan nasionalisme }\end{array}$ \\
\hline Prosedur Pembelajaran & $\begin{array}{l}\text { 1. Pendahuluan } \\
\text { 2. Pengajuan masalah, mengarahkan masalah, dan penjelasan } \\
\text { konsep } \\
\text { 3. Pengajuan hipotesis } \\
\text { 4. Penggalian informasi } \\
\text { 5. Pengujian hipotesis } \\
\text { 6. Penyusunan kesimpulan }\end{array}$ \\
\hline
\end{tabular}

Tabel 2. Tahapan Pembelajaran untuk Meningkatkan Kesadaran Sejarah Melalui Pendekatan Inkuiri

\begin{tabular}{|c|c|}
\hline Tahap & Kegiatan \\
\hline Pendahuluan & $\begin{array}{l}\text { 1. Pretest } \\
\text { 2. Tanya jawab atau diskusi tentang pokok bahasan yang telah } \\
\text { dipelajari } \\
\text { 3. Tanggapan terhadap informasi yang telah dipersiapkan } \\
\text { siswa } \\
\text { 4. Memajang media pembelajaran (gambar, foto, peta) }\end{array}$ \\
\hline Pengajuan permasalahan & $\begin{array}{l}\text { 1. Menjelaskan tujuan pembelajaran, pokok bahasan } \\
\text { 2. Membimbing dan mendorong diskusi pengajuan permasala- } \\
\text { han, dan indentifikasi permasalahan }\end{array}$ \\
\hline Pengajuan hipotesis & $\begin{array}{l}\text { 1. Penjelasan tentang hipotesis } \\
\text { 2. Membimbing dan mendorong siskusi menyusun hipotesis, } \\
\text { pengajuan hipotesis, dan meninjau hipotesis }\end{array}$ \\
\hline Penggalian informasi & $\begin{array}{l}\text { 1. Persiapan bahan-bahan } \\
\text { 2. Penjelasan tujuan penggalian informasi } \\
\text { 3. Membimbing dan mendorong siswa } \\
\text { 4. Identifikasi, mengumpulkan, menafsirkan, klasifikasi, dan } \\
\text { analisis }\end{array}$ \\
\hline Pengujian hipotesis & $\begin{array}{l}\text { 1. Penjelasan uji hipotesis } \\
\text { 2. Diskusi identifikasi urutan dan aturan, dan penetapan kepu- } \\
\text { tusan }\end{array}$ \\
\hline Pengajuan kesimpulan & $\begin{array}{l}\text { 1. Penjelasan tujuan kesimpulan } \\
\text { 2. Membimbing dan mendorong siswa } \\
\text { 3. Diskusi menemukan hubungan-hubungan antara informasi } \\
\text { dan hipotesis } \\
\text { 4. Diskusi merumuskan kesimpulan, dan menetapkan kesim- } \\
\text { pulan } \\
\text { 5. Tugas siswa } \\
\text { 6. Posttest }\end{array}$ \\
\hline
\end{tabular}

